\title{
What We Still Don't Know about Monetary and Fiscal Policy
}

Two THOUSAND AND SEVEN may seem an odd moment to question what we know about monetary policy. The past quarter-century has been about as good a run, at least in aggregate dimensions, as one is likely to getand certainly far superior to what the early Brookings Panel participants, in the 1970s, ever thought likely. The United States has experienced only two business recessions during the last twenty-five years, neither lasting longer than eight months and neither involving a decline in total production as great as $1 \frac{1}{2}$ percent. ${ }^{1}$ Annual price inflation has converged onto a $1 \frac{1}{2}$ to 2 percent norm, with the average increase apart from food and energy (the U.S. central bank's preferred measure) falling exactly in the middle of this range over the past ten years and not a single year as much as $1 / 4$ percentage point either above or below. Neither the severe one-day stock market crash in October 1987, nor the collapse of a good portion of the nation's thrift deposit industry in the late 1980s, nor the protracted stock market decline of 2000-03, nor the quadrupling of world oil prices since 2002 had much, if any, visible impact on either aggregate nonfinancial economic activity or economy-wide inflation. Euroland and most of the world's other advanced economies have enjoyed similarly favorable rides, and even the one outstanding exception—Japan — proves the rule, in that monetary policy there was so plainly wrong-headed. Among academic

I am grateful to Arturo Estrella, Robert Gordon, Kenneth Kuttner, Spence Hilton, and Daniel Thornton for helpful discussions and for comments on an earlier draft.

1. Output volatility has declined sharply on a more finely measured basis as well; see, for example, Blanchard and Simon (2001). 
economists it has become commonplace to hail the tremendous advances in knowledge about the subject, and even to refer to monetary policy, as practiced today, as a science. ${ }^{2}$

Fiscal policy today likewise seems on a surer footing of knowledge than in earlier eras. Despite the expense of simultaneously fighting two wars, and despite a tax cut that had put the U.S. government's budget on a path toward deficit even before either war began, the ratio of the government's outstanding interest-bearing debt to national income has fluctuated narrowly within the range of 0.33 to 0.37 since the beginning of the decade. (The government's unfunded liabilities, mostly for Social Security and Medicare, are another matter, but lack of knowledge is not the problem.) The experience of 2001, recalling that of 1981, has even led to some talk of tax cuts in particular as potentially efficacious in spurring recovery from recessions. For the most part, however, fiscal policy has mostly disappeared from discussion at both the popular and the academic levels.

Well-earned complacency notwithstanding, some modest reflection suggests that despite the recent gains in knowledge, several questions of some seriousness, about both monetary and fiscal policy, remain to be answered. Some are primarily conceptual, while others spring more directly from operational concerns. But in both of these policy areas, experience suggests that often what starts out as a largely conceptual inquiry leads, in time, to implications with practical import.

\section{A Conceptual Question: How Does the Central Bank Make Monetary Policy in the First Place?}

Most economics textbooks introduce the role of monetary policy by deriving one or more sources of demand for the central bank's liabilities: banks need reserves to satisfy reserve requirements and to settle interbank transactions, the nonbank public needs currency to conduct everyday business, and so on. The next step is to posit, reasonably enough, that the central bank is a monopoly supplier of its own liabilities and therefore can, unless directed otherwise by higher authorities, set that supply at whatever level it chooses. Because both the banks' and the nonbank public's demand for the central bank's liabilities is likely to be interest sensi-

2. The most widely cited example is probably Clarida, Galí, and Gertler (1999). 
tive, the equilibrium of demand and supply in this market establishes the price at which these liabilities are exchanged for other assets: conceptually, some kind of interest rate. Given the role of interest rates and asset returns more generally in affecting aggregate demand, the economic consequences of monetary policy actions - that is, of changes in the supply of central bank liabilities-follow with however much elaboration seems appropriate.

This idealized story bears essentially no resemblance to how most central banks today go about either formulating or conducting monetary policy. True, there was a time when many central banks, including the Federal Reserve System, carried out monetary policy either by setting the quantity or the rate of growth of the monetary base or by targeting the growth of some related measure of deposit money. But most central banks, including the Federal Reserve, gave up that practice some time ago. Instead most central banks today make monetary policy by setting some designated short-term interest rate (in the United States, the federal funds rate). ${ }^{3}$

According to standard representations, whether the central bank sets the quantity of its liabilities or the price at which those liabilities exchange for other assets is irrelevant except for stochastic considerations. (In the United States the federal funds rate is the price for borrowing central bank reserves overnight.) The central bank can set the quantity and let the market determine the equilibrium price, or it can set the price and let the market determine the equilibrium quantity. Either way, what the central bank is doing amounts to picking a point on the demand curve that it faces. Whether the supply curve it imposes is vertical or horizontal, or perhaps upward sloping, is of no consequence (again except for stochastic implications). What matters is only the point at which that supply curve intersects the demand curve.

The most glaring lacuna separating this idealized representation from reality is the implication that, unless the demand curve for central bank liabilities is nearly vertical, changing the interest rate requires nontrivial

3. For simplicity, the discussion here takes the interest rate as a primitive for purposes of monetary policy. There is, of course, an extensive literature on the determination of monetary policy as either a rule or, more generically, a reaction function, in either case based on economic developments to which policymakers respond. The most familiar example today is probably Taylor (1993), but the literature adopting this approach to monetary policymaking is much older; see, for example, Reuber (1964), Goldfeld and Blinder (1972), and Friedlaender (1973). 
changes in the quantity of outstanding central bank liabilities-in other words, open market operations. In fact, today most central banks need to undertake little if any market intervention to change the designated policy interest rate. A mere announcement is normally sufficient. ${ }^{4}$ Indeed, the Federal Reserve Bank of New York reports that in recent years even the announcement is often unnecessary. When a change in the Federal Open Market Committee's target for the federal funds rate is widely anticipated, market participants typically move the actual rate to the expected new target rate even before the committee has met to change the target. ${ }^{5}$ Increasingly, the operating arm of the central bank is not the trading desk but the press office.

Any of several different hypotheses might explain this phenomenon, but most raise more questions than they answer, and in any case none bears much connection to the way in which standard economic models introduce the role of the central bank. To begin, perhaps the demand for central bank liabilities actually is (approximately) vertical. One immediate difficulty, however, is that a large body of both theory and empirical research has consistently indicated significant negative interest elasticity in banks' demand for reserves and even, albeit to a lesser extent, in the public's demand for currency. Further, a nearly vertical demand for central bank liabilities would imply that even very small changes in reserve quantities, not matched by shifts in the demand curve, would lead to huge interest rate fluctuationsa plainly counterfactual proposition. Although most central banks today do a pretty good job of anticipating the day-to-day demand curve shifts that occur for a variety of technical reasons (shifts from one kind of deposit to another, changes in the government's cash balance, fluctuations in the float, gold flows, and so forth), no one pretends that this activity has achieved perfection. An explanation that implies large interest rate fluctuations any time the trading desk's daily technical estimate is off by a billion dollars or two is hardly satisfactory.

4. What is at issue here is movements along the demand curve for central bank liabilities. By contrast, as the experience of heightened market volatility just this past summer, in both the United States and Europe, has again shown, shifts in the demand curve are occasionally substantial, especially under conditions of falling prices for highly leveraged assets. Hence it sometimes takes large changes in the quantity of central bank reserves to maintain the policy interest rate at a given level.

5. See Hilton (2005). The bank has confirmed that the same pattern has also prevailed since then; see Federal Reserve Bank of New York (2007). 
A more familiar explanation is that because everyone understands that the central bank can carry out open market operations on even a vast scale, it is not necessary to do so: the mere threat is sufficient. ${ }^{6}$ Although this idea may seem plausible at first thought, it, too, is highly problematic. There is a difference between saying that private sector agents (in this case banks and other investors) are price takers in some market and saying that they take whatever price they are given without adjusting their portfolios accordingly. This explanation is also inconsistent with the fact that, from time to time, shifts in the demand for central bank liabilities do require sizable open market operations merely to maintain the existing policy interest rate (as was the case, most recently, in the summer of 2007).

Alternatively, once one leaves currency aside (and no central bank attempts to make monetary policy by rationing the supply of its currency), in many countries the remainder of the central bank's liabilities bulk sufficiently small that, even with an interest-elastic demand, only small changes in supply are needed to change the price. Reserves held by U.S. commercial banks and other depository institutions at year-end 2006 totaled only $\$ 43$ billion. Moreover, because $\$ 35$ billion of this amount consisted of vault cash, the amount held as balances with the Federal Reserve System was only $\$ 8$ billion. Just as the Federal Reserve (or, for that matter, even some large private collector) could presumably set the price of buffalo nickels wherever it chose by means of transactions that look tiny compared to the size of the U.S. economy, perhaps the Federal Reserve can manipulate this tiny market in the same way.

But no one believes that changing the price of buffalo nickels would have any impact on the broader vector of asset prices and interest rates that matter for purposes of influencing aggregate demand. The market for buffalo nickels is, in effect, "decoupled" from the asset markets more generally_or at least it would be if either the Federal Reserve or a large private collector were to manipulate their price in that way. ${ }^{7}$ By contrast,

6. Sometimes, of course, knowledge of the possibility of genuinely large-scale open market operations is important; presumably this was the point of Ben Bernanke's (2002) statement (as a Federal Reserve governor, not yet chairman) that "the U.S. government has a technology, called a printing press . . . that allows it to produce as many U.S. dollars as it wishes at essentially no cost." But that context was different from simply setting the federal funds rate by making announcements. More generically, see Goodhart (2000) for a discussion of this issue.

7. See Friedman (2000) for a more extended discussion of the concept of decoupling in this context. 
the whole point of using the federal funds rate as the operating instrument of monetary policy is precisely that changes in this price are presumed to have an influence on other interest rates and asset demands.

A yet more novel explanation, suggested by Michael Woodford, ${ }^{8}$ is that because what is at issue is the central bank's liabilities, private sector agents have no basis on which to price them in relation to other assets until the central bank itself gives them guidance. At the broadest level, Woodford's suggestion amounts to saying that the private sector's demand for central bank liabilities - to recall, the basis on which standard models introduce the role for monetary policy - is strictly notional (or, again, decoupled from other markets based on economic fundamentals), presumably because the services that those reserves provide have no intrinsic value. The case is similar to that of certain artistic creations: as if buyers have no way to judge whether a painting is worth $\$ 10,000$ or $\$ 10,000,000$ until the gallery selling it tells them what to think; and, moreover, they are prepared to change their minds on the matter whenever the gallery owner says so.

A perhaps more plausible interpretation of Woodford's idea is that because the liabilities being priced are nominal, and the central bank ultimately controls the economy's inflation rate, market participants know that the value of these liabilities in terms of other assets can be whatever the central bank wants. (This is yet a different way of saying that they have no intrinsic value.) But, to recall, the price being established is the rate at which overnight reserves exchange with other nominal assets. Further, because these are overnight obligations, and inflation over the relevant time horizon is not practically subject to central bank control anyway, investors presumably compare the real return on these assets with the returns on other assets as determined by fundamental economic considerations of thrift, productivity, and risk.

It should go without saying, although sometimes these things are important to say nonetheless, that the point of this line of inquiry is not that economists interested in monetary policy should follow "bumblebee" logic and deny that the central bank can set its policy interest rate. (A widespread myth has it that, according to accepted principles of aeronautical engineering, it is impossible for a bumblebee to fly. Yet bumblebees do fly, and central banks do set, and from time to time change, their policy interest rate.) Rather, the point is that when economists use models that

8. Woodford (2000). 
take as their starting point the central bank's setting some interest rate, they should be prepared to entertain the "How do they do that?" question. And to the extent that the answer implicit in most familiar treatments fails to meet the minimum requirements of plausibility in the world in which central banks make monetary policy today, that situation stands as a challenge to economic thinking.

\section{An Empirical Question: Where, and How, Does Monetary Policy Bite on the Real Economy?}

The early years of the Brookings Papers coincided with a florescence of work aimed at pinning down quantitatively the ways in which monetary policy influences nonfinancial economic activity, and the financial channels through which that influence takes place. Under the leadership of Franco Modigliani, often in collaboration with Albert Ando, researchers at the Federal Reserve and throughout the academic world built on then-new theoretical developments (for example, the permanent income hypothesis) and advances in empirical techniques (for example, in estimating systems of simultaneous equations) to examine systematically the various "channels" by which the central bank's actions influence the economy. For some purposes, of course, merely knowing the magnitude and timing of the aggregate impact would be sufficient. But in other contexts knowing what share of the impact would fall on business investment, or homebuilding, or consumer spending is of interest as well. Further, having some sense of the contents of the "black box" enhances the confidence to be attached even to aggregate estimates. Although no concise summary would do justice to the findings of such a broad-based empirical research program, two principal emphases emerged: the importance of impacts on consumer spending that took place through changes in asset values, primarily in the stock market; and the impact of deposit flows on residential construction, mostly as a result of institutional imperfections in the mortgage market. Conversely, the findings of this work mostly downplayed the straightforward interest elasticity of business investment, which had received much of the attention earlier in the post-World War II period. ${ }^{9}$

9. The initial reports were presented in DeLeeuw and Gramlich $(1968,1969)$, but in subsequent years this effort spawned numerous publications. 
A great deal has changed since that era. Both the development of new markets and the abolition of then-existing regulation have removed much of what James Tobin used to call the "sand in the wheels" that once gave monetary policy much of its bite. Most obviously, the establishment of a secondary market in home mortgages, supported by massive securitization through the federally sponsored companies, together with the removal of regulatory ceilings on interest paid on some key categories of deposits, has mostly eliminated the disintermediation of liabilities from mortgageissuing depository institutions that gave the housing market such pronounced sensitivity to swings in short-term interest rates. And securitization has extended well beyond the mortgage market. Today consumer loans, car loans, ordinary commercial and industrial loans, and many other standard forms of credit that originating lenders traditionally had to retain on their own balance sheet—even "distressed" loans—all readily trade in securitized form. ${ }^{10}$

The development of traded options and other derivative contracts is perhaps even more fundamental. To be sure, options (and futures) make it possible for both firms and individuals to hedge risks that they normally face. But the availability of these contracts also allows investors, if they choose, to take on pure risk unrelated to their underlying economic situation. Although the conventional assumption among economists is that speculation dominates hedging only when such markets are in an immature state, this conclusion remains as yet unsupported by experience. Credit derivatives are especially interesting in a monetary policy context, in that they undermine traditional presumptions about who bears the risk of default: the fact that a bank is the lead lender to some firm no longer bears any clear implication about whether that bank (or any other participating lender) is at risk if the firm were to default on its obligations.

The advancing globalization of economic activity in general and financial markets in particular, together with the unpegging of exchange rates following the collapse of the Bretton Woods system in the early 1970s, matters in each of these contexts and more besides. In the United States the share of the economy's markets for goods and services that is exposed to international competition, roughly approximated by the sum of imports

10. The idea that the economy may be evolving in these respects is hardly new. See Friedman (1989) for one attempt to measure the changes in the various ways in which monetary policy is effective. There have been many others. 
plus exports, has grown from less than 10 percent forty years ago to more than 25 percent today. Hence the potential effectiveness of monetary policy working through exchange rate changes is presumably that much greater (although there is evidence that the pass-through of exchange rate movements in the pricing of U.S. imports is often limited). Moreover, currency rates have fluctuated widely. For example, from the inception of the euro in 1999 to November 2007, the dollar-euro rate has swung between 0.84 and 1.46 .

Economists' concern with links among international markets in the context of monetary policy has also traditionally focused on "currency substitution" (which, as a practical matter, is really about deposits). Indeed, the increasing ease of currency substitution-along with innovations in deposit taking and the removal of regulation-was part of the reason for the collapse of the empirical relationships between various measures of money and either income or prices, which in turn led most central banks in the 1980s to dump their money growth targets in favor of setting an interest rate. In the absence of money growth targets, today the globalization of financial markets matters for monetary policy primarily on the asset side of institutions' balance sheets: what is the point of making credit more expensive in the United States if borrowers can easily find accommodation, at unchanged terms, from lenders abroad? Further, as recent experience has demonstrated, international redistribution of risks also matters. Not only is Enron's lead bank not necessarily at risk if the company defaults; it is entirely possible that no U.S. institution bears that risk.

Lessons learned from empirical research done a generation ago are therefore no longer reliable guides to the structure of monetary policy's influence on nonfinancial economic activity. To be sure, the Federal Reserve Board staff continues to maintain and update a macroeconometric model that represents the direct descendant of the original Modigliani-Ando-DeLeeuwGramlich-Pierce-Enzler-et al. enterprise. But models of this kind have mostly vanished from the purview of academic and academic-style research and debate in economics, and so even that effort has neither widely informed current thinking on such matters nor benefited from the usual process of evaluation, critique, and discussion. ${ }^{11}$

11. Fair (1994, chapter 1) discusses the consequences of the disappearance of macroeconometric modeling from the purview of the academic economic profession. 
Although in principle the idea of a large impact of monetary policy on consumer spending via stock prices looms all the larger today, now that institutional changes have blunted what used to be sizable rationing effects operating through the mortgage market (although not the elasticity of housing demand with respect to interest rates per se), this story has always been problematic in light of the limited overlap between who owns the stocks and who does the consuming. Although 49 percent of all American families now own stocks either directly or through mutual funds or retirement accounts (the percentage was far smaller when this research was done years ago), the median family holding is only $\$ 24,000 .{ }^{12}$ By contrast, the top 1 percent of households own 53 percent of all common stock held by households outside of retirement accounts, and 48 percent when stock held in retirement accounts is included. ${ }^{13}$

Roughly half of the impact of monetary policy via this channel, therefore, in principle represents the behavior of a very small number of people who hold very large amounts of assets. There is no reason to suppose that the individuals and families in this group are immune from the effect of changes in the value of the assets they own, as spelled out in the usual permanent income (or life cycle) model. But it is also implausible to suppose that these large-quantity asset holders regularly adjust their consumption in response to valuation changes over the fairly short time horizons typically considered in empirically estimated models of the economy's response to monetary policy. Neither Bill Gates nor Warren Buffett is going to decide whether to buy a new car, or take a vacation, or give a party this year because the value of his stock portfolio has changed.

By contrast, for the bulk of the population of stockholders, even if they take fully into account any fluctuations in the value of assets held in their retirement funds (already a dubious assumption), the amounts involved are too small to deliver the estimated aggregate response of consumer spending. For a $\$ 24,000$ holding, even a 10 percent change in value is just $\$ 2,400$; multiplying by 0.03 , the usual one-year impact coefficient found in this kind of research, gives a one-year consumption change of only $\$ 72$ per family. And for the 51 percent of families who own no stocks

12. These figures are based on the Federal Reserve's latest Survey of Consumer Finances; see Bucks, Kennickell, and Moore (2006).

13. See Poterba (2000). 
whatsoever (not even in retirement accounts), the impact implied by the standard story is zero.

None of this means, of course, that changes in stock prices might not imply changes in consumer behavior through some other channel-for example, even people who own no stock might interpret observed stock price changes as informative about future economic conditions and adjust their behavior accordingly. Nor does it rule out that stock price changes might simply be correlated with consumer behavior out of common dependence on some unspecified influence. But neither of those ideas is the same as the standard (for the last thirty or so years) story that monetary policy exerts its largest effect by changing stock prices, which in turn affect consumer spending along permanent income or life cycle lines.

\section{A Policy Question: Is Inflation Targeting Consistent with a Dual Mandate for Monetary Policy?}

Inflation targeting has become one of the most significant developments of recent decades in both the theory and the practice of monetary policy. A rapidly expanding literature has analyzed the a priori properties and the practical consequences of various inflation targeting strategies, and an increasing number of central banks around the world - at last count roughly two dozen, in both the advanced economies and the developing worldhave adopted one form or another of this strategy as the basic framework governing the formulation and implementation of their monetary policy. It is hardly surprising that one now sees frequent calls for the Federal Reserve System to join the parade and restructure U.S. monetary policy, too, within the guidelines of some form of inflation targeting. The recent change in leadership at the Federal Reserve has made the issue all the more prominent: former chairman Alan Greenspan opposed inflation targeting, but Ben Bernanke favors it.

Much of the discussion of this subject, within both the central banking and the academic communities, has focused on the empirical question of the consequences of adopting inflation targeting: Does doing so actually help a country reduce its average rate of inflation, or the volatility of inflation around that average, or is the role of inflation targeting more to lock in place gains in this arena already won? What consequences follow for the average level, or the volatility, of real outcomes such as growth and 
employment? Does inflation targeting improve the "sacrifice ratio" measuring the amount of output, or of employment, that an economy must forgo in order to reduce inflation from some embedded average rate to a lower average, or even to bring inflation back to a given long-run average after a temporary departure? More specifically for current U.S. purposes, what is the appeal of inflation targeting for a country that has alreadyindeed, long since-achieved a low and stable rate of inflation without any changes in its monetary policymaking institutions? Empirical research has delivered mixed and conflicting results on each of these questions. ${ }^{14}$

The U.S. central bank is unusual in that, under the prevailing legislation by which the Congress has delegated this important policymaking power to the Federal Reserve, the central bank is instructed to conduct monetary policy so as to promote both maximum employment and stable prices. ${ }^{15}$ This "dual mandate," as it is often called, stands in contrast to the charge given many other countries' central banks to focus primarily or even exclusively on maintaining stable prices. The Bank of England's "remit," for example, instructs that central bank to achieve price stability and only then, to whatever extent is possible within the price stability constraint, to seek favorable outcomes for real economic activity. The European Central Bank's charter is ambiguous about whether price stability is to be that central bank's only objective or merely the (overwhelmingly) lead one within a strict hierarchy.

As Arthur Okun and Franco Modigliani, and especially James Tobin, frequently reminded us, the purpose of any nation's economic policy is to advance its economic well-being, meaning the prosperity of its citizens and the vitality of the institutions through which they participate in economic activity, both in the present and for the future. Whether working men and women are able to make a living, whether the businesses that they own and at which they work can earn a profit and invest adequately for

14. Compare, for example, the findings reported in Ball and Sheridan (2003) with those of Levin, Natalucci, and Piger (2004).

15. The legislation also includes a third objective: low long-term interest rates. Most practically oriented discussions ignore this part of the mandate, however, both because this objective is largely redundant (given the inclusion of maximum employment and price stability) and because, to the extent that it is not redundant, there is little if anything that monetary policy - as distinct from the Federal Reserve's management of its asset porfolio, for example—can do to achieve it. 
future growth, and whether the banks and other financial institutions on which both individuals and businesses rely can survive in the face of the risk taking that is central to their reason for existing are all fundamental aspects of that well-being. Individual citizens are, and have a right to be, concerned with many facets of the economic environment in which they live: their incomes, their employment prospects, their ability to start a business or to borrow to purchase a new home, just to name a few. Monetary policymakers also have both practical and historical reasons for seeking to maintain the vitality of financial institutions and the functioning of financial markets. As the collapse of the savings and loan industry in the late 1980s once again showed, the impairment of an economy's banking system can interrupt the credit creation process, destroy asset values, and otherwise impede the ability of households and firms to carry out their ordinary economic affairs.

Experience shows that rising (or falling) prices can and sometimes do undermine the efficiency of economic activity, and therefore price stability is a key desideratum in all of these regards. But price stability is instrumental, valued not for itself but for how it enhances an economy's capacity to achieve those goals that, even if they are not genuinely primary from the perspective of basic human concerns, are at least instrumental at a higher level. The idea that economic policy should pursue price stability as a means of promoting more fundamental economic well-being, either currently or in the future, is not ground for pursuing price stability at the expense, much less to the exclusion, of that more fundamental economic well-being.

Further, it is not legitimate to duck the question of whether and how monetary policy should seek to affect real economic outcomes by subsuming that question within the prior one of whether monetary policy can do so. Both theory and evidence indicate that, in an economy like that of the United States, monetary policy can affect not just prices but also output, employment, and other important aspects of nonfinancial economic activity, and can affect them over at least some significant period. ${ }^{16}$ The relevant question is in what way it should seek to do so.

Perhaps the easiest way to illustrate the question at issue here is to take seriously—if only briefly — the opposite prospect: Imagine that the House

16. For a survey of the pertinent evidence, see Blanchard (1990). 
or Senate Financial Services Committee were welcoming the Federal Reserve's chairman for his or her semiannual report on monetary policy. Suppose that the economy had been spiraling downward for nearly a year, the unemployment rate were in double digits, industrial production were sharply down from the previous peak, corporate bankruptcies and home mortgage foreclosures were accelerating, and banks were beginning to fail in large numbers. And now suppose that, in the midst of this economic disaster, the Federal Reserve chairman were to begin his or her testimony as follows: "I am pleased to report that during the past year U.S. monetary policy has been outstandingly successful. Overall inflation has again been just 1.0 percent, and prices other than for food and energy have risen by just 0.9 percent. My colleagues and I are here to accept this committee's congratulations and those of the American people."

Such a situation is, of course, unthinkable. But the relevant question is what makes it so. More specifically, to the extent that the dual mandate that Congress has assigned to the Federal Reserve System is an important element underpinning the implausibility of such a perverse fantasy, the question is whether inflation targeting is consistent with monetary policymaking under a dual mandate.

In principle, as many advocates of inflation targeting have emphasized, inflation targeting need not imply that the chosen inflation rate is policymakers' sole objective, and so in principle an inflation targeting regime can be consistent with a dual mandate. ${ }^{17}$ With only one instrument at their disposal, it is possible (apart from situations of model degeneracy) for monetary policymakers to describe their intended economic trajectory in terms of only one variable. ${ }^{18}$ The appeal of doing so in terms of inflation, rather than output or employment, rests on the presumption that in the long run monetary policy cannot affect those real outcomes, which instead ultimately depend only on factors such as endowments, preferences, and technologies. Hence, by choosing inflation for this purpose, policymakers are focusing on a variable that monetary policy can influence not just over the medium horizon but in the long run as well.

Advocates of inflation targeting, both within central banks and among academic researchers, mostly ground the argument in its favor on consid-

17. See, for example, King (1997), who famously coined the phrase "inflation nutter" to refer to a policymaker having objectives with respect to inflation only.

18. The basic principle is due to Tinbergen (1952). 
erations of transparency and accountability. The argument for the greater transparency of an inflation targeting strategy fails, however-and with it the argument for greater resulting accountability—when policymakers have objectives for real economic outcomes, as under the dual mandate that Congress has assigned to the Federal Reserve. In that case inflation targeting is more likely to undermine the transparency of monetary policy than to promote it.

The chief reason is that under inflation targeting policymakers normally reveal to the public only one of their multiple objectives: that for inflation. If outsiders knew (and were able to use) the economic model on which policymakers rely in evaluating potential actions, the public could infer what path for output or employment, or any other variable of interest, would be expected to accompany the targeted inflation trajectory. (They could also back out the central bank's intended path for interest rates.) But few central banks operate with such a single economic model, and further, few disclose this information anyway. Nor do inflation-targeting central banks quantify for the public_-or, normally, even for themselves-the relative importance that they attach to their objectives for inflation and for real economic outcomes. ${ }^{19}$

To the contrary, most inflation-targeting central banks at least appear to go to some effort not to reveal such aspects of their policymaking to the public, and indeed to avoid giving any impression that considerations other than preserving price stability figure importantly, or even at all, in their decisions. An increasingly common practice, for example, following the initial lead of the Bank of England, is to issue at regular intervals a detailed monetary policy report, but to call it an "Inflation Report"-as if inflation were the only aspect of economic activity of concern to monetary policy. Similarly, many inflation-targeting central banks, in the public explanation that they provide of the rationale underlying their monetary policy strategy, as well as in their public statements about monetary policy more generally, avoid any reference to the possibility of tension, even in the short run, between their inflation objective and any real outcome.

In light of the favorable effect on short-run inflation-output trade-offs that standard forward-looking representations of the price setting process,

19. Using just this line of reasoning, Lars Svensson has advocated having the central bank be specific internally in all of these respects and publicly disclose all of this information; see, most recently, Svensson (2007). 
like the neo-Keynesian Phillips curve, imply from keeping expectations of future inflation anchored at a low level, the incentive for policymakers to downplay or even conceal their objectives for real economic outcomes is clear enough. ${ }^{20}$ But their doing so hardly contributes to the transparency of their policy. In parallel, if policymakers have objectives for both inflation and real outcomes, but disclose only their inflation objective, then Congress as well as the general body politic can hold them accountable in an explicit way at most for their success or failure in meeting their inflation objective; the rest must rely on inference and guesswork.

Whether inflation targeting is consistent with a U.S.-type dual mandate for monetary policy, and to what extent inflation targeting leads to desirable properties of monetary policy when the central bank does operate under a dual mandate, are therefore questions of some seriousness for the United States. Given the time horizons over which the key processes at issue play out-importantly including matters of public perception and of central bank accountability, to higher political authority as well as to financial market participants and the general public-it is not a question to be lightly addressed by experimentation. Nor does most of the conventional empirical research methodology that economists employ naturally lend itself to being informative on the issue. Yet the stakes are high, and so whatever light future research can shed on the question is well worth the effort.

\section{And Two Questions about Fiscal Policy}

Fiscal policy as such has generated little interest in the United States in recent years, apart from the ongoing discussion of what to do about the unsustainable trajectories for Social Security and especially Medicare. Yet two questions-one about policymaking over business cycle frequencies and one about the long run-seem pertinent today.

At the time of the Brookings Papers' inception, many economists saw deliberate variation in either tax or spending policy as a useful means to help dampen unwanted fluctuations in aggregate economic activity. The idea was an old one, especially as it involved government spending, and

20. For example, see Clarida, Galí, and Gertler (1999). 
the record of New Deal programs like the Civilian Conservation Corps and the Works Progress Administration in putting people to work and adding to aggregate demand during the recovery from the 1930s' depression had lent it further credibility. Investment tax credits, aimed at influencing the timing of business capital spending with the same goal in mind, also seemed to be a useful tool (and they fit well within the cost-of-capital approach to modeling investment). Nor was the purpose always to be stimulative: in 1968 the government had imposed a temporary income tax surcharge aimed at preventing aggregate demand from exceeding full-employment benchmarks at the height of the Vietnam War effort. In time, however - and partly as a result of the perceived failure of the 1968 measure-economists lost interest in the idea of using discretionary fiscal actions for countercyclical stabilization. One reason was the longstanding concern with both the delay in decisionmaking and the lags with which policy, once decided, affected the economy (the so-called "inside" and "outside" lags, respectively), in the context of difficulty in predicting what shocks to the economy would need to be offset when. Numerous studies of that time examined the record of various fiscal actions to see whether they took place during recessions, or if not, then how far into the recovery they occurred, and whether they managed to stimulate aggregate demand within the subsequent recovery. But theory mattered as well. If consumers behaved according to the permanent income (or the life cycle) model, the impact on their spending due to tax changes not believed to be permanent would be minor.

What has put this issue back on the agenda today, or at least on the fringes of it, is the experience of 1981 and, most recently, 2001. In both instances the economy was in recession. In both instances Congress enacted sizable tax cuts while the recession was still in progress. And in both instances the tax cuts evidently boosted aggregate demand and hence helped accelerate the return to full employment. For a variety of reasons, these two episodes may not be informative-at least not in terms of the traditional debate over the potential efficacy of discretionary countercyclical fiscal policy. The intent of the framers of both the 1981 and the 2001 tax cuts was to make them permanent. Further, both measures were "in the pipeline," having already been advocated for reasons having nothing to do with combating recession, well before the recession began. But that is almost always true. Many people in the United States, including many holders of political office, would like to cut tax rates further, while 
at the same time many others would like to raise some tax rates. Both groups consist largely of people who intend the cuts, or the increases, that they advocate to be permanent. The motivating goal is not to rectify any deficiency or excess of aggregate demand but to address some longer-run issue: reducing disincentives for private economic initiative, or narrowing the government's fiscal imbalance. Similarly, there is never any lack of proposals for new government spending programs. (Asymmetrically, despite the usual rhetoric about reducing government spending, there are normally very few concrete proposals to eliminate or reduce existing programs.) It is not difficult, therefore, to picture a ready supply of proposals that have been offered on other grounds and are waiting to be adopted, just as the 1981 and 2001 tax cuts were, at a time when they might be useful for this supplementary purpose. The question is whether the systematic use of such measures would be a positive addition to the arsenal of economic policy.

Finally, what about the long run? Early participants on the Brookings Panel had seen the U.S. government's interest-bearing debt decline from more than one dollar for every dollar of a year's national income, at the end of World War II, to less than 30 cents per dollar of national income. The reason was not budget surpluses, but simply deficits that were almost always small enough to keep the stock of debt growing more slowly than the economy grew in nominal terms. Over the next decade the ratio moved little, and by the beginning of the 1980s it stood at 0.26. Few economists anticipated the near doubling (to 0.49) that took place during the Reagan-Bush Sr. years. Likewise, few anticipated the Clinton surpluses that then brought the ratio back down. Today the government's debt ratio stands at 0.37 , having been as low as 0.33 at the beginning of this decade.

Other advanced industrial countries today exhibit widely varying amounts of government debt outstanding compared with their total production and income. Japan's reported government debt-to-income ratio (as of 2006) is the highest, at 1.79 (although this figure is not comparable to the U.S. equivalent for a variety of reasons, most prominently the inclusion of debt held in government-owned accounts). In Italy the debt ratio today is 1.20 - higher than America's was at the end of World War II. In Belgium it is 0.91 . At the other end of the scale, the debt ratio is only 0.16 in Australia, 0.25 in New Zealand, and 0.30 in Ireland. Among the 
other Group of Seven countries, the ratio is 0.68 in Canada, 0.75 in France, 0.71 in Germany, and 0.47 in the United Kingdom. ${ }^{21}$

The question is whether any of this matters. Clearly many people think it does. In the United States, discussion of either Social Security or Medicare routinely emphasizes the explosive trajectory for the government's debt ratio implicit in maintaining the current structure of these programs as the population ages. In Europe one of the stated criteria determining a country's eligibility to join the new common currency, as specified under the 1992 Maastricht Treaty, was that its government debt ratio be 0.60 or below, or at least that the country be making progress toward that goal.

For purposes of short-run analysis, what matters about the government debt ratio is not so much its level but whether it is rising or falling. This distinction, however, is just the same as whether the government's budget deficit is large or small, and so what is involved in terms of economic effect is no more than the usual analytics of how budget deficits matter. In the United States, with approximately $\$ 5$ trillion of government debt now held by the public, and with the economy growing at a nominal rate of approximately 6 percent a year (the average over the past two years), a rising or falling government debt ratio merely means that the annual deficit is above or below $\$ 300$ billion, respectively.

But what about the long run? Presumably the government debt ratio cannot rise (or fall) indefinitely; that is the point of the usual discussion of Social Security and Medicare. Equilibrium requires some stable level. Wholly apart from whether the ratio is rising or falling in any particular span of a few years, does it matter whether a country has outstanding government debt equal to half a year's national income, or twice that income? And if so, how does it matter?

21. International debt-income ratios are from the OECD's Economic Outlook database. Issues of measurement (including the treatment of government debt held in governmentowned accounts, differences in what debt is issued by the central government and what by the equivalent of state or local governments, and the like) prevent these figures from being anything more than suggestive of the relevant cross-country differences. A more fundamental question is whether countries that participate in the European common currency any longer have genuine "government debt" in the traditional sense; from a conceptual standpoint, the obligations issued by these governments are more like state or municipal bonds in the American context. 
Some parts of the answer are fairly straightforward analytically, although the key magnitudes at issue are subject to dispute. Presumably having more government debt to service means having to raise more revenue, all else equal, and in the absence of lump-sum taxes this means a greater deadweight loss in the form of reduced incentives to work or invest, as well as increased operational costs. On the other side, having a large and liquid market for debt instruments with no default risk improves the efficiency of the markets for private obligations as well. The U.S. corporate bond market, for example, operates in a very different way todayboth in the pricing of new issues and in the opportunities for hedging positions, and therefore for the implied cost of bearing risk-than it did thirty years ago when legislative restrictions effectively prevented the Treasury from issuing long-term bonds. In addition, outstanding nominal debt theoretically provides flexibility in the government's response to economic shocks, in that it can implicitly default on part or all of these obligations through inflation-although the prospect of doing so flies in the face of not just calls for inflation targeting but the entire direction of the discussion of monetary policy over the last three decades. ${ }^{22}$

Other aspects of the question, however, are less certain even analytically. To the extent that the holders of the government's debt are not the same as the taxpayers whose payments will service it, or to the extent that those holders fail to internalize the connection even if the ultimate debtservice liability does fall on them (and both of these considerations appear to be empirically important), government debt is an asset in the eyes of the public. ${ }^{23}$ Holding either more or less of it therefore affects the desired composition of the public's portfolio of other assets and liabilities, importantly including the desired stock of productive physical capital. Does having a government debt ratio of two to one therefore limit an economy's equilibrium capital intensity, compared with an economy where the ratio is one to two? And what difference does it make if, as in the United States today, the country is a chronic borrower from abroad, so that a substantial fraction of the government's debt (as of 2006, 44 per-

22. See Hall and Krieger (2000), for example, for an exposition of this idea.

23. As Barro (1974) pointed out, the issue here is the extent to which government debt is a net asset to the public that holds it. The subject has generated an enormous empirical literature; see, for example, Bernheim (1987), Seater (1993), and Elmendorf and Mankiw (1999). 
cent) is owned by foreign investors? $?^{24}$ And to what extent are nonmarketed implicit liabilities, like those for future payments of Social Security and Medicare benefits, equivalent to market-held debt for purposes of such questions? These liabilities currently dwarf the federal government's market debt but they bear no interest and therefore impose no explicit deadweight loss associated with debt service.

Finally, and still more fundamentally, if the answer is that having one government debt ratio versus another makes no difference for anything real that matters in the economy, is the presumption that the economy must have some stable level in equilibrium valid? That is, if going from a debt ratio of $X$ today to, say, $1.5 X$ a decade from now makes no real difference, why could the ratio not increase by 50 percent in the following decade as well, and then again in the decade after that and the decade after that? Presumably there are reasons why it cannot. (Again, matters such as deadweight burdens of revenue collection are one potential story, although only if the debt service is not also perpetually financed.) But understanding in practical terms what those reasons are, and over what time horizon they operate, would usefully inform thinking on fiscal policy at a more fundamental level than the ongoing debate normally encompasses.

\section{References}

Ball, Laurence, and Niamh Sheridan. 2003. "Does Inflation Targeting Matter?" Working Paper 9577. Cambridge, Mass.: National Bureau of Economic Research (March).

Barro, Robert J. 1974. “Are Government Bonds Net Wealth?” Journal of Political Economy 82, no. 6 (November): 1095-1117.

Bernanke, Ben S. 2002. "Deflation: Making Sure 'It' Doesn't Happen Here." Remarks before the National Economists Club, Washington, November 21.

Bernheim, B. Douglas. 1987. "Ricardian Equivalence: An Evaluation of Theory and Evidence." In NBER Macroeconomics Annual 1987, edited by Stanley Fischer. MIT Press.

24. At one level the issue here is the classic distinction between debt owed to oneself (or one's heirs) and debt owed to others. In practice the matter is actually more subtle: does it matter whether foreign investors own U.S. Treasury bills directly or own deposits in U.S. banks, which in turn hold the Treasury bills? 
Blanchard, Olivier Jean. 1990. "Why Does Money Affect Output? A Survey." In Handbook of Monetary Economics, vol. 2, edited by Benjamin M. Friedman and Frank H. Hahn. Amsterdam: North-Holland.

Blanchard, Olivier, and John Simon. 2001. "The Long and Large Decline in U.S. Output Volatility." BPEA, no. 1: 135-64.

Bucks, Brian K., Arthur B. Kennickell, and Kevin B. Moore. 2006. "Recent Changes in U.S. Family Finances: Evidence from the 2001 and 2004 Survey of Consumer Finances." Federal Reserve Bulletin 92: A1-A38.

Clarida, Richard, Jordi Galí, and Mark Gertler. 1999. "The Science of Monetary Policy: A New Keynesian Perspective.” Journal of Economic Literature 37, no. 4 (December): 1661-1707.

DeLeeuw, Frank, and Edward M. Gramlich. 1968. "The Federal Reserve-MIT Econometric Model." Federal Reserve Bulletin 54 (January): 11-40. 1969. "The Channels of Monetary Policy: A Further Report on the Federal Reserve-MIT Econometric Model." Federal Reserve Bulletin 55 (June): 472-91.

Elmendorf, Douglas W., and N. Gregory Mankiw. 1999. "Government Debt." In Handbook of Macroeconomics, vol. 1C, edited by John B. Taylor and Michael Woodford. Amsterdam: Elsevier Science.

Fair, Ray C. 1994. Testing Macroeconometric Models. Harvard University Press.

Federal Reserve Bank of New York. 2007. "Domestic Open Market Operations during 2006." Report prepared for the Federal Open Market Committee by the Markets Group of the Federal Reserve Bank of New York (February).

Friedlaender, Ann F. 1973. "Macro Policy Goals in the Postwar Period: A Study in Revealed Preference." Quarterly Journal of Economics 87, no. 1 (February): 25-43.

Friedman, Benjamin M. 1989. "Changing Effects of Monetary Policy on Real Economic Activity." In Monetary Policy Issues in the 1990s. Federal Reserve Bank of Kansas City.

2000. "Decoupling at the Margin: The Threat to Monetary Policy from the Electronic Revolution in Banking." International Finance 3, no. 2 (July): 261-72.

Goldfeld, Stephen M., and Alan S. Blinder. 1972. "Some Implications of Endogenous Stabilization Policy.” BPEA, no. 3: 585-640.

Goodhart, Charles A. E. 2000. "Can Central Banking Survive the IT Revolution?" International Finance 3, no. 2 (July): 189-209.

Hall, George J., and Stefan Krieger. 2000. "The Tax Smoothing Implications of the Federal Debt Paydown." BPEA, no. 2: 253-84.

Hilton, Spence. 2005. "Trends in Federal Funds Rate Volatility." Federal Reserve Bank of New York Current Issues in Economics and Finance 11, no. 7 (July): $1-7$. 
King, Mervyn A. 1997. "Changes in U.K. Monetary Policy: Rules and Discretion in Practice." Journal of Monetary Policy 39, no. 1 (June): 81-97.

Levin, Andrew T., Fabio M. Natalucci, and Jeremy M. Piger. 2004. "The Macroeconomic Effects of Inflation Targeting." Federal Reserve Bank of St. Louis Review 86, no. 4 (July/August): 51-80.

Poterba, James M. 2000. "Stock Market Wealth and Consumption." Journal of Economic Perspectives 14, no. 2 (Spring): 99-118.

Reuber, G. L. 1964. "The Objectives of Canadian Monetary Policy, 1949-61: Empirical 'Trade-offs' and the Reaction Function of the Authorities." Journal of Political Economy 72, no. 2 (April): 109-32.

Seater, John J. 1993. "Ricardian Equivalence." Journal of Economic Literature 31, no. 1 (March): 142-90.

Svensson, Lars E. O. 2007. "Optimal Inflation Targeting: Further Developments of Inflation Targeting." In Monetary Policy under Inflation Targeting, edited by Frederic S. Mishkin and Klaus Schmidt-Hebbel. Santiago: Banco Central de Chile.

Taylor, John B. 1993. "Discretion Versus Policy Rules in Practice." CarnegieRochester Conference Series on Public Policy 39 (December): 195-214.

Tinbergen, Jan. 1952. On the Theory of Economic Policy. Amsterdam: NorthHolland.

Woodford, Michael. 2000. "Monetary Policy in a World without Money." International Finance 3, no. 2 (July): 229-60. 


\section{General Discussion}

Lawrence Summers suggested that although no one has explicitly rejected the Akerlof-Dickens-Perry analysis, no central bank has explicitly adopted that analysis in making monetary policy. The idea that the wage mechanism behaves differently at 1 percent annual inflation than at $2 \frac{1}{2}$ percent inflation does not appear to be an important factor in central bank decisionmaking. Insofar as central banks have adopted higher inflation targets, this has occurred not because of concern about unemployment, but because of concern about the implications of deflation for real interest rates.

George Perry replied that the Akerlof-Dickens-Perry ideas actually did get some attention at the Federal Reserve and other central banks. A common theme in the literature before the mid-1990s was that zero inflation is ideal, even though people have understood the potential negative consequences of deflation for a long time. Therefore the apparent decision by the Federal Reserve not to pursue zero inflation may reflect some concern about the trade-off with unemployment.

William Dickens added that the Bank of New Zealand had expressly considered this research when making its decision to increase its inflation target. Further, when many economists were advocating zero inflation in the 1990s, he, Akerlof, and Perry argued that this option should be taken off the table, and this has since happened. In fact, all inflation-targeting central banks currently target inflation in the 1 to 2 percent range. 
